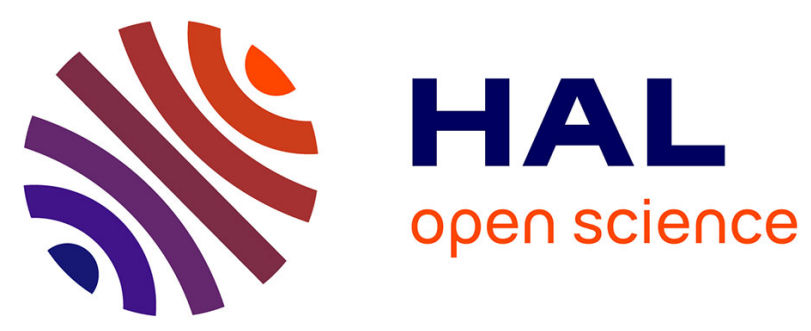

\title{
Contrasting geophysical and geochemical signatures of a volcano at the axis of the Wharton Fossil Ridge (N-E Indian Ocean)
}

\author{
Hélène Hébert, Benoit Villemant, Christine Deplus, Michel Diament
}

\section{- To cite this version:}

Hélène Hébert, Benoit Villemant, Christine Deplus, Michel Diament. Contrasting geophysical and geochemical signatures of a volcano at the axis of the Wharton Fossil Ridge (N-E Indian Ocean). Geophysical Research Letters, 1999, 26 (8), pp.1053-1056. 10.1029/1999GL900160 . insu-01354338

\section{HAL Id: insu-01354338}

\section{https://hal-insu.archives-ouvertes.fr/insu-01354338}

Submitted on 18 Aug 2016

HAL is a multi-disciplinary open access archive for the deposit and dissemination of scientific research documents, whether they are published or not. The documents may come from teaching and research institutions in France or abroad, or from public or private research centers.
L'archive ouverte pluridisciplinaire HAL, est destinée au dépôt et à la diffusion de documents scientifiques de niveau recherche, publiés ou non, émanant des établissements d'enseignement et de recherche français ou étrangers, des laboratoires publics ou privés. 


\title{
Contrasting geophysical and geochemical signatures of a volcano at the axis of the Wharton fossil ridge (N-E Indian Ocean)
}

\author{
Hélène Hébert, Benoît Villemant, Christine Deplus ${ }^{1}$, Michel Diament \\ Institut de Physique du Globe, Paris, France
}

\begin{abstract}
The Styx volcano is a prominent seamount (20$30 \mathrm{~km}$ diameter, $2500 \mathrm{~m}$ high) located at the axis of the Wharton fossil spreading center (N-E Indian Ocean), where seafloor spreading stopped $40 \mathrm{Ma}$ ago. Gravity modeling shows that it was emplaced on a weak lithosphere, in agreement with an on axis origin when seafloor spreading was active. The rocks dredged at the summit of the volcano are extreme typical alkaline basalts, indicating a deep enriched mantle source. We show here that most of this seamount was emplaced during the final stage of the seafloor spreading in the Wharton Basin. We then discuss how alkaline magmatism can be emplaced at the summit of the Styx.
\end{abstract}

\section{Introduction and geodynamic setting}

This paper discusses the origin of a seamount located at the axis of the fossil spreading center in the Wharton Basin (N-E Indian Ocean), through its geophysical and geochemical characteristics. The seamount was discovered during the Samudra cruise (R/V L'Atalante, december 1995) [Deplus et al., 1996] and was named Styx.

Seafloor spreading stopped in the Wharton Basin (figure 1) during the kinematic reorganization which affected the Indian Ocean at the Eocene [Patriat and Ségoufin, 1988], followed by the initiation of seafloor spreading at the Southeast Indian Ridge. Few data [Liu et al., 1983] were available before the Samudra cruise to precisely define the axis of the Wharton fossil spreading center. The new data collected during this cruise [Deplus et al., 1998; Hébert, 1998] consist of multibeam bathymetry and back-scatter data, gravity, magnetics, 6-channel seismic, $3.5 \mathrm{kHz}$ profiling, and two dredges.

Three EW segments of the Wharton fossil ridge have been identified from the magnetic anomalies and the morphology of the basement deduced from bathymetric and seismic data. The magnetic anomalies show that the half spreading rate rapidly evolved from fast (about $6 \mathrm{~cm} / \mathrm{y}$ at $50 \mathrm{Ma}$ ) to slow (about $2 \mathrm{~cm} / \mathrm{y}$ at $40 \mathrm{Ma}$ ) values, before cessation of spreading which is estimated at $38 \mathrm{Ma}$ [Hébert, 1998]. The bathymetric data reveal the presence of two prominent seamounts (Styx and Hellas, figure 2). Hellas is proposed to be an inside corner high of the fossil ridge [Hébert, 1998], with dredged basalts having a typical MORB signature.

${ }^{1}$ Also at Centre National de la Recherche Scientifique

Copyright 1999 by the American Geophysical Union.

Paper number 1999 GL900160.

0094-8276/99/1999GL900160\$05.00
The Styx volcano (at least $2500 \mathrm{~m}$ high and a mean diameter of about $20 \mathrm{~km}$ ) interrupts the axial valley of the about $100 \mathrm{~km}$ long westernmost axial segment (figure 2). This valley is elsewhere 20 to $30 \mathrm{~km}$ wide and about 1000 to $2000 \mathrm{~m}$ deep. Thus the volcano height should have reached more than $3000 \mathrm{~m}$ above the floor of the former axial valley elsewhere covered with thick sediments (500 to $1000 \mathrm{~m}$ ).

\section{Mode of emplacement of the seamount deduced from gravity data}

\subsection{Method and data}

A successful method to distinguish between the possible origins of seamounts is to study the flexure of the lithosphere due to the loading of the volcano, [e.g. Watts et al., 1980; Menard and McNutt, 1982; Watts and Ribe, 1984]. The flexure of the lithosphere can be characterized by its equivalent elastic thickness $\left(T_{e}\right)$, which is in oceanic domain, at first order, proportional to the square root of the age of the lithosphere at the time of loading [Watts et al., 1980]. Since the elastic model is only an equivalent model and since thermal rejuvenation can occur [Menard and McNutt, 1982], this method can not be used to determine a precise age. But it can be used to determine whether the major part of the load was emplaced on-ridge (lithosphere $0-5 \mathrm{Ma}$ old) or off-ridge (lithosphere older then 10-15 Ma) [Watts and Ribe, 1984; Goslin and Diament, 1987].

Assuming that the lithospheric flexure is parallel to the crust-mantle boundary, we determine the elastic thickness by modeling the gravity data with various Moho geometries (constrained by various $\mathrm{T}_{e}$ ). The free air anomaly contains the gravity effects of the water/sediment, sediment/crust and crust/mantle interfaces. As the lateral thermal variations due to mantle upwellings beneath the axis have disappeared at a fossil spreading center $40 \mathrm{Ma}$ old, the corresponding gravity effect need not be taken into account. But we must account for the preexisting axial depression. The preexisting valley is modeled with a flat $6500 \mathrm{~m}$ deep bottom and bounded by a rectangular shape inferred from the seismic and magnetic data (dashed line in figure 2). The preexisting Moho is defined as parallel to the valley, by assuming a $6 \mathrm{~km}$ thick crust. All computations are made in the spectral domain [Parker, 1972] in 3 dimensions. We discuss results for two profiles, one along and one across the axis (location on figure 2).

\subsection{Results}

For both profiles (figure 3) and for any crustal density between 2600 and $2900 \mathrm{~kg} \cdot \mathrm{m}^{-3}$, the free air anomaly is best fit (RMS $<2 \mathrm{mGal}$ ) with a low equivalent elastic thickness 


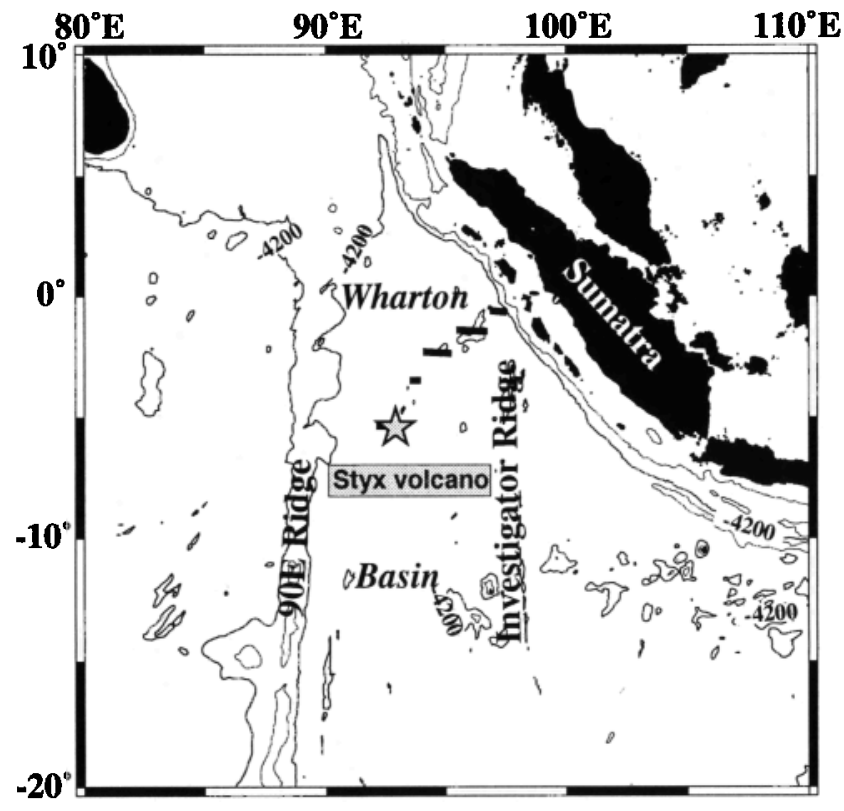

Figure 1. Sketch of the geodynamic setting of the Wharton Basin, which is bounded by the $90 \mathrm{E}$ Ridge to the west and the Sumatra trench to the east. The location of the three westernmost segments of the fossil spreading ridge is deduced from the interpretation of magnetic anomalies identified with the data of the Samudra cruise. The Styx volcano is located on the westernmost segment and is shown with the grey star.

$\left(\mathrm{T}_{\mathrm{e}}<4 \mathrm{~km}\right)$. For a crustal density of $2700 \mathrm{~kg} \cdot \mathrm{m}^{-3}$, the best model is obtained for $T_{e}=1 \mathrm{~km}$. This result suggests that the volcano was formed on-axis. Indeed to reconcile a very low rigidity with a lithosphere older than 10-20 Ma, a ther- mal rejuvenation hypothesis seems unsuitable for the Wharton Basin. On the other hand, the presence of the fossil normal faults bounding the axial valley might have decreased the rigidity of the lithosphere. We modeled the deflection of a faulted lithosphere in response to the topographic load of the Styx volcano, with various equivalent elastic thicknesses by using the 3D analytical method developped by Wessel [1996]. All attempts to reproduce a significant flexure with a rigidity higher than with $\mathrm{T}_{e}=5 \mathrm{~km}$ failed. It is thus unlikely that the volcano formed on a plate older than $10 \mathrm{Ma}$. In addition, basalts dredged at the summit are sometimes well vesiculated, indicating an eruption under a low water column (that is $<1000 \mathrm{~m}$ ). The subsidence laws [Stein and Stein, 1992] predict that the sea-bottom deepens by about $2500 \mathrm{~m}$ after $40 \mathrm{Ma}$, corresponding to the present depth of the summit of the volcano. Based on all these results we suggest that the volcano was emplaced about $40 \mathrm{Ma}$ ago during the final activity of the Wharton ridge.

\section{Geochemical results}

The dredge performed close to the summit of the Styx volcano collected large quantities of carbonate rocks and few volcanic rock fragments which consist of altered basaltic lavas. No radiometric data are available because of sample alteration, but this alteration and the presence of a thick sedimentary cover suggest that the volcano was not recently active. All volcanic products have been analysed by XRF for major elements and INAA for trace elements.

Surprisingly all volcanic fragments are typical alkali basalts $\left(\mathrm{SiO}_{2} \simeq 45 \%\right)$ with high $\mathrm{Ti}$ and alkali contents $\left(\mathrm{TiO}_{2} \simeq\right.$ $2.4 \%$ and $\mathrm{Na}_{2} \mathrm{O}+\mathrm{K}_{2} \mathrm{O} \simeq 5.4 \%$ ). Their composition pattern normalized to N-MORB (figure 4a) displays a characteristic enrichment in incompatible elements (50 times MORB concentrations for $\mathrm{Rb}, \mathrm{Ba}$ and $\mathrm{Th}$ ) with no negative $\mathrm{Ta}$ and $\mathrm{Ti}$

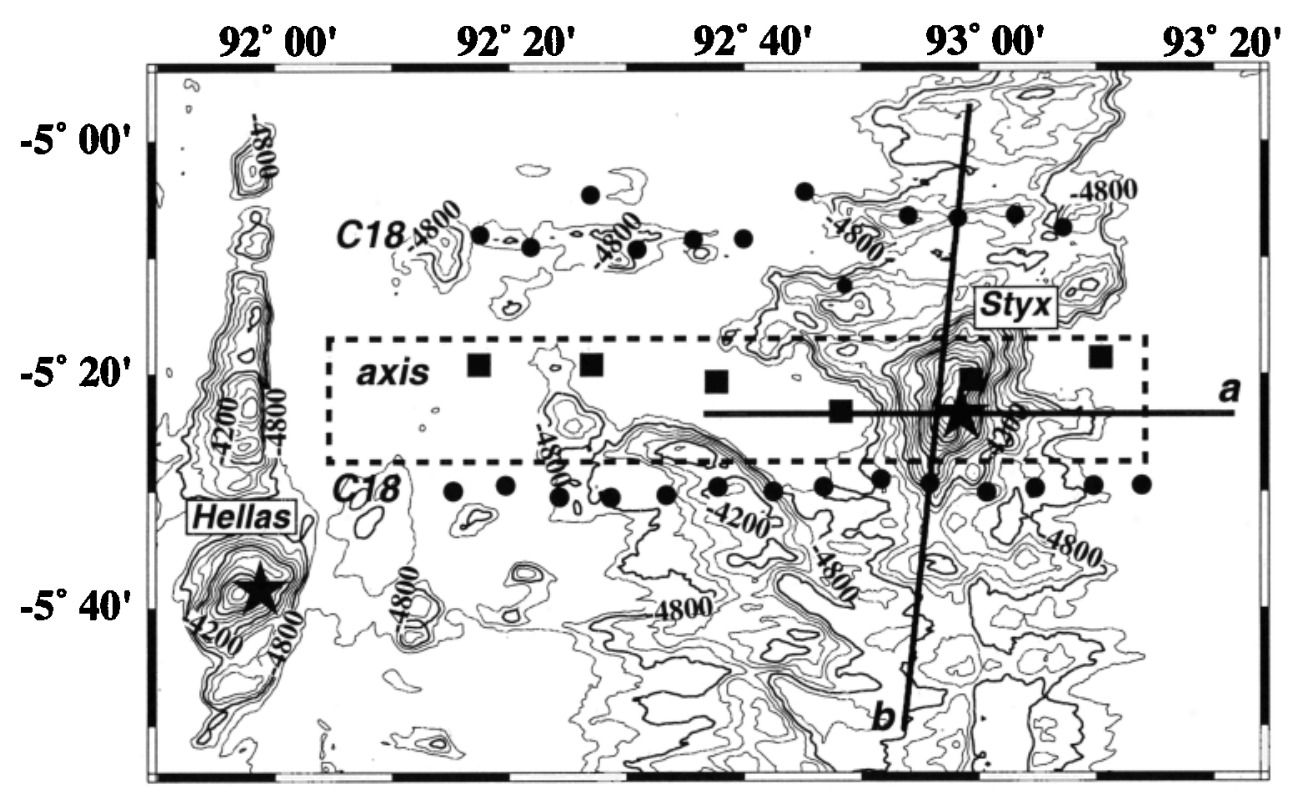

Figure 2. Bathymetric map compiled from multibeam data gathered during the Samudra cruise (isobaths $150 \mathrm{~m}$ ). The location of the axis (squares) and of chron 18 (C18 - 40.1 Ma, circles) are deduced from magnetic anomalies along NS tracks. Limits of the preexisting axial valley (dashed line) are inferred from seismic data and magnetic anomalies. The two profiles modeled in figure 3 are represented with solid black lines. The black stars indicate the approximate locations of the dredged basalts. 

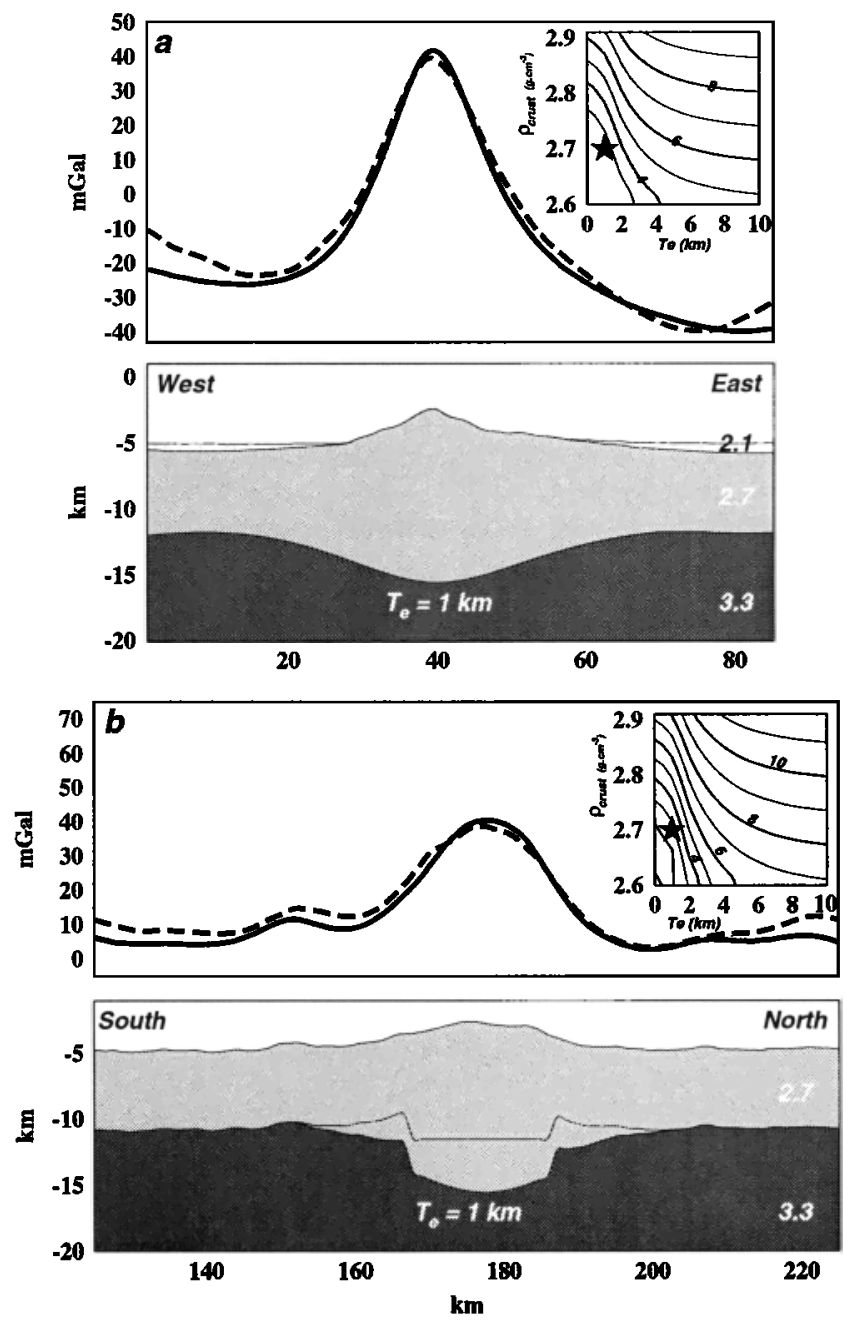

Figure 3. Crustal models for two profiles across the Styx volcano ( $a$ and $b$, location on figure 2): upper mantle (black), crust (grey) and sediments (light grey). For both profiles, the free air anomaly (dashed lines) is well fitted by the model with $T_{e}=1 \mathrm{~km}$ (solid line) and $\rho_{c}=2700$ $\mathrm{kg} \cdot \mathrm{m}^{-3}$. RMS values (mGal) obtained when varying $T_{e}$ and the crustal density $\rho_{\mathrm{c}}$ are plotted in the insets.

anomaly. In addition, the Styx basalts display the most enriched character ever encountered for Indian Ocean basalts (figure $4 \mathrm{~b}$ ). Thus the volcanic rocks dredged at the Styx seamount are produced from a pure enriched mantle source. On the contrary the volcanic samples dredged at the Hellas volcano are typical N-MORB (figure 4).

\section{Discussion}

The geophysical results indicate that most of the Styx volcano was emplaced on-ridge. How such an edifice can be built on the axial valley? Volcanoes as huge as the Styx seamount are not observed in the axial valleys of slow spreading ridges despite the important bathymetric coverage available. But a few high reliefs have been observed at the ultra slow Southwest Indian Ridge, interrupting the axial valley [Patriat et al., 1997] and displaying gravity signatures [Rommevaux-Jestin et al., 1997] similar to that of the Styx volcano. They have been interpreted as resulting

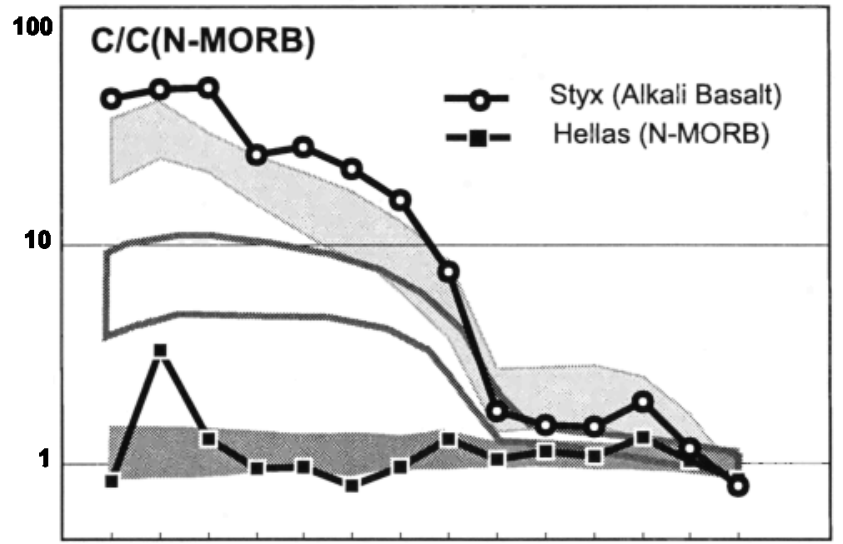

Rb Ba Th U Ta K La CeSm Hf TI Eu Tb Yb

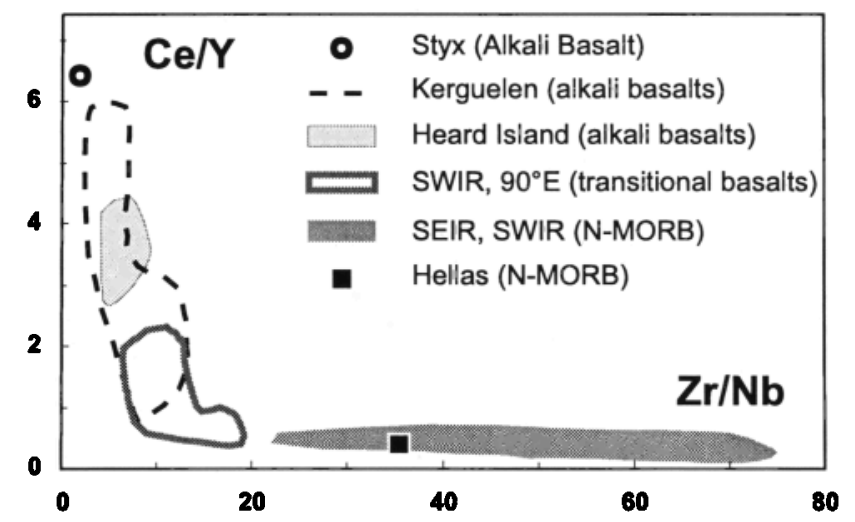

Figure 4. Trace element composition patterns of basalts dredged in the Wharton fossil spreading center, compared to basalts from the Indian Ocean. a: Composition of basalts normalized to $\mathrm{N}-\mathrm{MORB}$. b: $\mathrm{Ce} / \mathrm{Y}$ vs $\mathrm{Zr} / \mathrm{Nb}$ diagram. Circles: basalts from the Styx volcano exhibiting an extreme alkaline signature. Squares: basalts from the Hellas volcano showing a typical N-MORB signature (C/C $\mathrm{N}-$ MORB $\approx 1$ ). Data sources from LeRoex et al. [1983], Class et al. [1996], Frey and Weis [1996] and references therein.

from the focusing of magmatic activity at very low spreading rate [Cannat et al., 1997]. Similarly, the Styx volcano could have been emplaced during the terminal activity of the Wharton Ridge, when the magmatic production decreased before stopping.

The geochemical analysis does not display any MORB component in the basalts dredged on the Styx. This implies the presence of a pure enriched mantle source (i.e. a plume) beneath the ridge. Data collected during the Samudra cruise show no evidence of any plume activity around the Styx volcano, thus this plume should have been of limited extent in time and space. Was this plume active during the terminal activity of the Wharton ridge, or long after? Since no dating is available for the basalts dredged, we discuss the two possiblities.

In the first case, as observed for the SEIR, the 90E Ridge, the interaction between a plume and an active ridge produces intermediate magma compositions (figure 4), and by no way such an extreme alkaline signature. How can we explain the lack of evidence for mixing of the sources? We may suppose that in the particular case of the Wharton 
dying ridge, the upper mantle contribution was drastically reduced. It may have allowed the migration of pure alkaline basalts from the plume, without any mixing with the upper convective mantle. Basalts have been dredged close to the summit of the Styx volcano, and this does not exclude that the bottom of the Styx may contain basalts with a more transitional character.

We can also propose a two-step emplacement for the Styx volcano. The major part of the edifice was formed during the terminal activity of the Wharton ridge. Then, additional volcanism involving a pure enriched mantle source occurred on the preexisting volcano. Such multiphased emplacements have already been proposed for oceanic features of the Indian Ocean and for South Pacific seamount chains [Diament and Baudry, 1987; Goslin and Diament, 1987; McNutt et al., 1997].

To conclude, we note that a large zone of the Wharton basin is covered by numerous seamounts (the emerged part of two of them are the Cocos and Christmas islands), but that the origin of this intraplate volcanism is not well understood. A detailed rock sampling with radiometric measurements of the Styx volcano and of these other seamounts would be necessary to determine their origin and mode of emplacement, and thus would contribute to the understanding of intraplate volcanism and plume/ridge interactions.

Acknowledgments. We are grateful to the Captain and crew of the N/O L'Atalante during the Samudra cruise. We thank J. Ségoufin, E. Humler for useful discussion, and P. Wessel for providing its 3D modeling program. We also thank Keith Louden and an anonymous reviewer for constructive reviews. Wayne Crawford kindly improved the English of the manuscript. Most of figures were generated using GMT (Generating Mapping Tool) [Wessel and Smith, 1991], and seismic data were processed using Seismic Unix [Cohen and Stockwell, 1996]. Contribution IPGP $\mathrm{n}^{\circ} 1595$.

\section{References}

Cannat M., C. Rommevaux-Jestin, D. Sauter, V. Mendel and C. Deplus, Focussed volcanism and the segmentation of the very slow spreading Southwest Indian Ridge (SWIR) (abstract), $E O S$ Trans. $A G U, 78$, Fall Meet. Suppl., F682, 1997.

Class, C., S.L. Goldstein and S.J.G. Galer, Discussion of "Temporal evolution of the Kerguelen plume: geochemical evidence from 38 to 82 Ma lavas forming the Ninetyeast Ridge" by F.A. Frey and D. Weis, Contrib. Mineral. Petrol., 124, 98-103, 1996.

Cohen, J.K., and J.J.W. Stockwell, CWP/SU: Seismic Unix release 28: a free package for seismic research and processing, Center for Wave Phenomena, Colorado School of Mines, 1996.

Deplus, C., M. Diament, J. Dubois, H. Hébert, P. Patriat J.-J. Sibilla, G. Bertrand, S. Dominguez, J. Malod, and B. Pontoise, The Wharton Fossil Ridge: preliminary results of a $3 \mathrm{D}$ geophysical survey (abstract), EOS Trans. $A G U$, 77, Fall Meet. Suppl., F960, 1996.

Deplus, C., M. Diament, H. Hébert, G. Bertrand, S. Dominguez, J. Dubois, J. Malod, P. Patriat, B. Pontoise, and J.-J. Sibilla Direct evidence of active deformation in the eastern Indian Ocean plate, Geology, 26, 131-134, 1998.

Diament, M., and N. Baudry, Structural trends in the Southern Cook and Austral archipelagoes (South Central Pacific) based on an analysis of SEASAT data: geodynamic implications, Earth Planet. Sci. Lett., 85, 427-438, 1987.
Frey, F.A., and D. Weis, Reply to the Class et al. discussion of "Temporal evolution of the Kerguelen plume: geochemical evidence from 38 to 82 Ma lavas forming the Ninetyeast Ridge", Contrib. Mineral. Petrol., 124, 104-110, 1996.

Goslin, J., and M. Diament, Mechanical and thermal isostatic response of the Del Cano Rise and Crozet Bank (southern Indian Ocean) from altimetry data, Earth Planet. Sci. Lett., 84, 285-294, 1987.

Hébert, H., Etudes géophysiques d'une dorsale naissante (dorsale d'Aden à l'Ouest de $46^{\circ} \mathrm{E}$ ) et d'une dorsale fossile (dorsale de Wharton) : implications sur les processus de l'accrétion océanique, et la déformation intraplaque dans l'Océan Indien, Thèse de Doctorat, 372 p., Université Paris 7, October 1998.

LeRoex A.P., H.J.B. Dick, A.J. Erlank, A.M. Reid, F.A. Frey, and S.R. Hart, Geochemistry, mineralogy and petrogenesis of lavas erupted along the South Wes Indian Ridge between the Bouvet triple junction and $11^{\circ} \mathrm{E}, J$. Petr., 24, 267-318, 1983.

Liu, C., J.R. Curray, and J.M. McDonald, New constraints on the tectonic evolution of the eastern Indian Ocean, Earth Planet. Sci. Lett., 65, 331-342, 1983.

McNutt, M.K., D.W. Caress, J. Reynolds, K.A. Jordahl, and R.A. Duncan, Failure of plume theory to explain midplate volcanism in the southern Austral islands, Nature, 389, 479-482, 1997.

Menard, H.W., and M. McNutt, Evidence for and consequences of thermal rejuvenation, J. Geophys. Res., 87, 8570-8580, 1982.

Parker, R.L., The rapid calculation of potential anomalies, Geophys. J. R. Astron. Soc., 31, 447-455, 1972.

Patriat, P., and J. Ségoufin, Reconstruction of the Central and Western Indian Ocean, Tectonophysics, 155, 211-234, 1988.

Patriat, P., D. Sauter, M. Munschy, and L.M. Parson, A survey of the Southwest Indian Ridge axis between Atlantis II FZ and the Indian Ocean Triple Junction: regional setting and large scale segmentation, Mar. Geophys. Res., 19, 457-480, 1997.

Rommevaux-Jestin, C., C. Deplus, and P. Patriat, Mantle Bouguer Anomaly along a super-slow spreading ridge: comparison with the central Mid-Atlantic Ridge and implications on the accretionary process, Mar. Geoph. Res., 19, 481-503, 1997.

Stein, C.A., and S. Stein, A model for the global variation in oceanic depth and heat flow with lithospheric age, Nature, 359, 123-129, 1992.

Watts, A.B., J.H. Bodine, and N.M. Ribe, Observations of flexure and the geological evolution of the Pacific Ocean basin, Nature, 283, 532-537, 1980.

Watts, A.B. and N.M. Ribe, On geoid heights and flexure of the lithosphere at seamounts, J. Geophys. Res., 89, 11152-11170, 1984.

Wessel, P., and W.H. Smith, Free software helps map and display data, EOS Trans. $A G U, 72,445-446,1991$.

Wessel, P., Analytical solutions for 3-D flexural deformation of semi-infinite elastic plates, Geoph. J. Int., 124, 907-918, 1996.

H. Hébert, C. Deplus, M. Diament, Laboratoire de Gravimétrie et Géodynamique, UMR 7577, IPGP, 4, place Jussieu, 75252 Paris Cedex 05, France. (e-mail: hebert@ipgp.jussieu.fr; deplus@ipgp.jussieu.fr; diament@ipgp.jussieu.fr)

B. Villemant, Laboratoire de Géochimie Comparée et Systématique, UMR 7579, Université Paris VI et IPGP, 4, place Jussieu, 75252 Paris Cedex 05, France. (e-mail: villemant@ipgp.jussieu.fr)

(Received December 1, 1998; revised February 10, 1999; accepted February 23, 1999.) 